\title{
Sarmaşık Filmi ve Sinematik Mekân Kullanımı üzerine Bir İnceleme: İktidarın Evreleri ve (Erk)eklik - İktidar İlişkisi
}

\author{
Mehmet ŞENER ${ }^{1 *}$
}

öz

İktidar, hiyerarşi ve erkeklik olguları; birçok sanat ve sosyal bilim dalında olduğu üzere sinemada da bazen tekil, bazen de farklı unsurlarla bağlantılı olarak ve çeşitli yönleriyle mercek altına alınmıştır. Tüm bu konuların etkili bir sinema diliyle izleyiciye aktarılmasında ise çeşitli sinematik unsurlar yanında, mekânsal anlatı ile mekân seçimi ve kullanımındaki başarı düzeyinin de belirleyici bir rolü vardır. Bu çerçevede yazıda, iktidar ve hiyerarşinin kaynağı ve temel karakteristikleri ile iktidarın varlığını sürdürme adına geçirebildiği değişimleri anlama düşüncesi üzerine yapılan 2015 yılı yapımı Sarmaşık adlı Türk filmi incelenecektir. Film, hikâyesi, karakterleri, iktidar ve hiyerarşi olgularına yaklaşımı ve getirdiği bakış açıları ile başta mekânın filmdeki rolü olmak üzere sinematik özellikleri çerçevesinde değerlendirilecek; erkeklik olgusu ise filmin bütününde durduğu yer üzerinden ve filmin ana temalarını oluşturan iktidar ve hiyerarşi olguları ile ilişkisi bağlamında ele alınacaktır.

\section{Sarmaşık Movie and A Study on Sinematic Space Usage: The Phases of Rulership and a Masculinity Phenomenon}

\begin{abstract}
The power, hierarchy and masculinity facts are examined in cinema either singularly or in connection with different factors as also made in art and social science branches. The success level in spatial narrations and venue selection and usages in addition to several cinematic components has a determinant role on the transfer of all these issues to audiences with an effective cinema language. In this framework, the Turkish movie Sarmaşık (2015) is examined in this article which is produced on the idea of understading the sources of power and hierarchy, their basic characteristics and the changes that power could undergo for survival. It is evaluated within the framework of its story, approaches to power and hierarchy and its cinematic properties that the role of space being in the first place; as to masculinity fact, it is examined through its place in the film and relationship with power and hierarchy.
\end{abstract}

Keywords: Power, Hierarchy, Masculinity, Sinematic Space, Sarmaşık Movie

\footnotetext{
${ }^{1}$ Kocaeli Üniversitesi, Mimarlık ve Tasarım Fakültesi, Mimarlık Bölümü, germinal msener@yahoo.com *ilgili yazar / Corresponding author: Mehmet ŞENER, germinal msener@yahoo.com Gönderim Tarihi: 07.12.2016

Kabul Tarihi: 20.12 .2016
} 


\title{
Sarmaşık Filmi ve Sinematik Mekân Kullanımı üzerine Bir İnceleme: İktidarın Evreleri ve (Erk)eklik - İktidar İlişkisi
}

\author{
Mehmet ŞENER ${ }^{1 *}$
}

ÖZET

İktidar, hiyerarşi ve erkeklik olguları; birçok sanat ve sosyal bilim dalında olduğu üzere sinemada da bazen tekil, bazen de farklı unsurlarla bağlantılı olarak ve çeşitli yönleriyle mercek altına alınmıştır. Tüm bu konuların etkili bir sinema diliyle izleyiciye aktarılmasında ise çeşitli sinematik unsurlar yanında, mekânsal anlatı ile mekân seçimi ve kullanımındaki başarı düzeyinin de belirleyici bir rolü vardır. Bu çerçevede yazıda, iktidar ve hiyerarşinin kaynağı ve temel karakteristikleri ile iktidarın varlığını sürdürme adına geçirebildiği değişimleri anlama düşüncesi üzerine yapılan 2015 yılı yapımı Sarmaşık adlı Türk filmi incelenecektir. Film, hikâyesi, karakterleri, iktidar ve hiyerarşi olgularına yaklaşımı ve getirdiği bakış açıları ile başta mekânın filmdeki rolü olmak üzere sinematik özellikleri çerçevesinde değerlendirilecek; erkeklik olgusu ise filmin bütününde durduğu yer üzerinden ve filmin ana temalarını oluşturan iktidar ve hiyerarşi olguları ile ilişkisi bağlamında ele alınacaktır.

Anahtar sözcükler: Iktidar, Hiyerarşi, Erkeklik, Sinematik Mekân, Sarmaşık Filmi

\section{Sarmaşık Movie and A Study on Sinematic Space Usage: The Phases of Rulership and a Masculinity Phenomenon}

\begin{abstract}
The power, hierarchy and masculinity facts are examined in cinema either singularly or in connection with different factors as also made in art and social science branches. The success level in spatial narrations and venue selection and usages in addition to several cinematic components has a determinant role on the transfer of all these issues to audiences with an effective cinema language. In this framework, the Turkish movie Sarmaşık (2015) is examined in this article which is produced on the idea of understading the sources of power and hierarchy, their basic characteristics and the changes that power could undergo for survival. It is evaluated within the framework of its story, approaches to power and hierarchy and its cinematic properties that the role of space being in the first place; as to masculinity fact, it is examined through its place in the film and relationship with power and hierarchy.
\end{abstract}

Keywords: Power, Hierarchy, Masculinity, Sinematic Space, Sarmaşık Movie

\footnotetext{
${ }^{1}$ Kocaeli Üniversitesi, Mimarlık ve Tasarım Fakültesi, Mimarlık Bölümü, germinal msener@yahoo.com *ilgili yazar / Corresponding author: Mehmet ŞENER, germinal msener@yahoo.com Gönderim Tarihi: 07.12.2016

Kabul Tarihi: 20.12.2016
} 


\section{GíRiş}

İktidar olgusu, bireysel yönelimlerin ve toplumsal hayatın şekillenmesi noktasında oynadığı belirleyici rolün de etkisiyle, çeşitli sanat dalları eliyle inceleme altına alınır. Bu bağlamda, konunun sıklıkla ve çok çeşitli yönlerden ele alındığı sanat dallarının başında sinema gelir. Sinemada, özellikle 1980li yıllardan sonra artarak ele alınmaya başlanan ve iktidar olgusuyla sık sık yolu kesişen konulardan biri de erkeklik olgusudur. Her iki konu başlığı için geçerli olmak üzere, ele alınan herhangi bir konunun sinema yoluyla etkili bir şekilde izleyiciye aktarılmasında ise disipline ait senaryo, görüntü yönetimi ve kurgu gibi temel sinematik unsurlar yanında mekân kavramının yeri ve kullanım biçimlerinin de önemli bir yeri vardır. Bu çerçevede makalede, iktidar ilişkileri ve evrelerini inceleyen, merkezde yer alan bir unsur olmasa da erkeklik olgusunu çeşitli yönleriyle irdeleyen ve mekânsal öğeler ile mekân kullanımını etkin sinematik anlatım öğeleri olarak kullanan 2015 yılı yapımı Türk filmi Sarmaşık ele alınacaktır. Film esas olarak yukarıda belirtilen konu başlıklarını ele alma noktasında izlediği yöntemler, tercih ettiği sinematik yaklaşım ve araçlar ve hikâyesi yoluyla iletmek istediği mesajlar çerçevesinde incelenecektir. Filmin merkezinde iktidar ilişkileri üzerine bir inceleme yer almakta ve bu yönüyle politik sinema özellikleri barındırmakta olup, makalenin kavramsal çerçevesi oluşturulurken bu konu başlıklarını esas alan bir yaklaşım sergilenecektir. Bu bağlamda, konuya ilişkin film çalışmaları literatürünü de göz önüne alan film okumaları gerçekleştirilirken, politik sinema kavramı ve benzer politik sinema örneklerinin incelenmesi üzerinden de bir tartışma yürütülecektir. Öte yandan, karakterler ve aralarındaki iletişimin incelenmesi üzerinden filmde iktidar ilişkilerinin ele alınma biçimine dair değerlendirmeler de yapılacaktır. Erkeklik olgusu ise filmde genellikle süregelen iktidar mücadelesinin bir parçası olarak ortaya çıktığı için, ağırlıklı olarak cinsiyetçilik ya da cinsellik bazında ifade ettiği anlamlar üzerinden değil, iktidar ilişkileri noktasında teşkil ettiği yer üzerinden ele alınacaktır.

Yazının ilk bölümünde filmin olay örgüsü, karakterleri ve ele aldığı konulara ilişkin sinematik özellikleri ana hatlarıyla ele alınacaktır. Sonraki kısımda ise iktidar ilişkileri ve hiyerarşi temaları; benzer sinema örnekleriyle karşılaştırmalı okumalar yapılması, sahne okumaları ve karakter çözümlemeleri yoluyla ele alınarak; filmin konuya nasıl yaklaştığı ve hangi pencerelerden baktığına dair analizler yapılacaktır. Sonrasında ise erkeklik olgusu, filmde teşkil ettiği yer ve iktidar olgusu ile ilişkisi noktasında nerede durduğu üzerinden tartışılacaktır. Son kısımda ise, filmin anlatmak istediği hususları etkili bir şekilde izleyiciye aktarmasında belirgin bir rol oynayan sinematik mekân kullanımları ele alınacak olup, sonuç bölümünde de ele alınan tüm konulara dair genel bir değerlendirme yapılacaktır.

\section{SARMAŞIK FILMI: OLAY ÖRGÜSÜ VE SINEMATOGRAFIK ÖZELLIKLERI}

Yönetmen Tolga Karaçelik'in Gişe Memuru'ndan sonra ikinci uzun metrajlı filmi olan Sarmaşık, gerek yurt içinde, gerekse yurt dışında pek çok festivalde gösterilerek çeşitli ödüller alır. ${ }^{2}$ (Şekil 1) Psikolojik gerilim türünde bir film olan Sarmaşık, Afrika'ya giderken armatörünün iflas etmesi üzerine liman otoritesinin emriyle demirlemek zorunda kalan bir yük gemisinde geçer (Şekil 2). Filmin hikâyesi, denizcilik hukuku gereğince haciz kaldırılana kadar gemide kalması gereken beş gemici ve kaptan Beybaba arasında, "gemi durdukça ve dönüşe dair haber çıkmadıkça" ortaya çıkan huzursuzluk, çekişme ve gerilimler çerçevesinde şekillenen iktidar ilişkileri üzerine

\footnotetext{
${ }^{2}$ Film, 2015 yılı Antalya Altın Portakal Film Festivali'nde En iyi Film, En iyi Yönetmen, En İyi Senaryo ve En iyi Erkek Oyuncu" ödüllerini alır. Ayrıca pek çok uluslararası film festivalinde gösterilen film; "Britanya'nın en büyük film festivallerinden biri olan East End Film Festivali’nden ‘En İyi Film’ ödülü” ve İtalya'nın kayda değer film festivallerinden biri olan "17. Cinema Europa Festivali'nden de Cinemaeuropa ödülleriyle" döner (Kültür Servisi, 2016).
} 
kuruludur (Günerbüyük, 2015). Film, Samuel Taylor Coleridge'in Yaş/ı Gemici adlı şiir kitabından alınan ve hikâyenin akışına ilişkin ipuçları vererek anlatımı tamamlayıcı bir işlev gören dizelerle, üç parçaya bölünmek suretiyle ilerler. "Karakterlerin geçmişine dair küçük bir fikir verme ve gemi hiyerarşisini izleyiciye aktarma" düşüncesiyle ana karakterlerin tek kare görüntülerinin olduğu açılış sahneleri ile başlayan film; "karmaşa"nın hâkim olduğu ve gemide mevcut hiyerarşik yapı ile sonrasında kalacak karakterlerin tanıtıldığı, bunu izleyen 20 dakikalık bölümle devam eder (Karaçelik, 2015b). Bu çerçevede filmin başında bir şeylerden kaçma halinin anlatıldığı dizelerde de vurgulandığı üzere, gemide kalan karakterlerin bir bölümünün, önceki hayatlarına ait sorunlardan kaçarak gemiye geldikleri görülür.

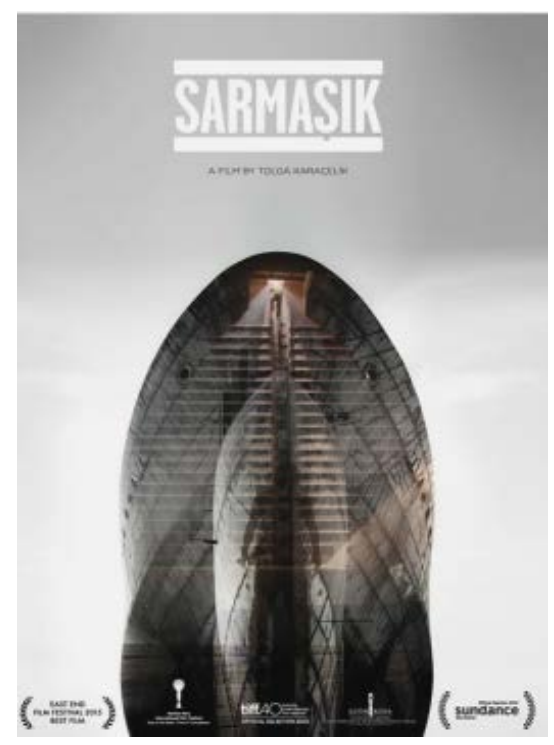

Şekil 1: Film, 2015 yılı içerisinde çeşitli ulusal ve uluslar arası film festivallerinden ödüller alır. (Kaynak: http://www.beyazperde.com.tr)

Filmin ikinci bölümünde ise geminin durarak işlevsizleşmesi, hiyerarşinin anlamını yitirmesine rağmen etkinliğini sürdürmek istemesi ve temel yaşamsal ihtiyaçların dahi karşılanamaz hale gelmeye başlaması sonrasında karakterler arasında ortaya çıkan gerilim ve iktidar mücadelelerine tanıklık edilir. Son bölüm ise, çaresizlik duygusunun zirveye çıkması ve iktidar etkisinin dayanılmaz hale gelmesi ile birlikte çatışma ortamı ve otorite mücadelesinin zirveye taşındığı, karakterlerin paranoyaklaşma ve çıldırma emareleri göstermeye başladığı ve fiziksel şiddetin açığa çıktığı bir süreçte ilerleyerek, izleyici yorumuna açık bir sonla film tamamlanır.

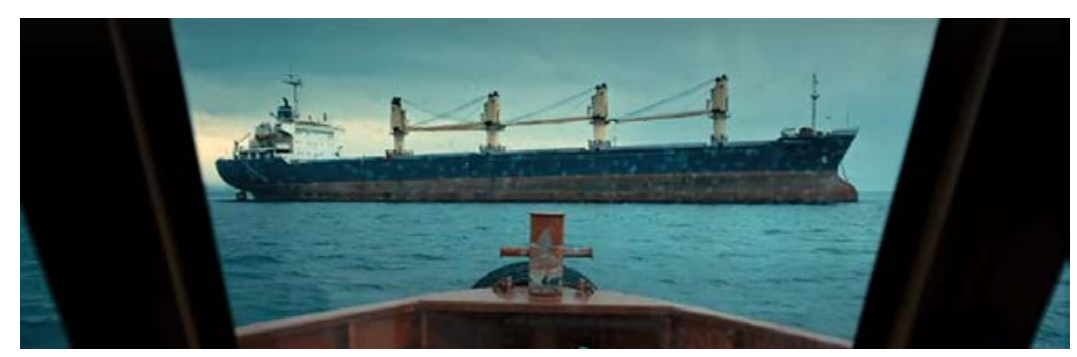

Şekil 2: Filmde kullanılan yük gemisi (Kaynak: http://www.vizyonfilmizle.com.tr/39540sarmasik-2015-yerli-film-izle.html)

Demirleme alanına götürülerek bağlanan geminin hareket ettirilmesini zorunlu kılan anlarda görev yapmak için gemide kalan altı kişiden "biri zabit, ikisi gemici, biri 
makineci, biri mutfak görevlisi ve sonuncusu da usta gemicidir." (Korkut, 2015) (Şekil 34) Filmin ana karakteri olan Cenk, iktidara karşı ilk tepkiyi veren, gemi öncesi hayatında dolandırıcılık yapan ve uyuşturucu kullanan bir karakterdir. (Şekil 5) İsmail ise filmin sonuna kadar Beybaba'nın otoritesine boyun eğen ve hiyerarşik yapıda bu otoriteyi Beybaba adına kullanan muhafazakâr bir kişidir. Nadir karakteri de maddi zorluklar nedeniyle gemide kalmak zorunda olan, otoriteye saygılı ve gemideki durumun etkisiyle bunalıma girerek zaman zaman intihara meyleden bir kişidir. Cenk'in gemideki en yakın arkadaşı olan Alper ise "gemicilikte acemi" olan ve yine gemiye önceki hayatından uzaklaşmak için gelen "keş" bir tiptir (Gönülşelen, 2015). Diğer bir karakter ise, adının sorulduğu bir sahne dışında film boyunca hiç konuşmayan ve bir süre sonra fiziksel varlığı da belirsizleşen, ancak güçlü metafizik etkisi film boyunca devam eden makineci Kürt figürüdür. Son karakter ise hiyerarşinin en başındaki kişi olarak gemide film boyunca hüküm süren gerilimin ana kaynağı olan kaptan Beybaba'dır. Yönetmen Karaçelik, filmdeki bu karakterlerin ve yazdığı gemi hikâyesinin bütünüyle kurmaca olmadığını, birçoğunu yapmış olduğu gemi yolculuklarında biriktirdiği gözlemler sonucunda belirlediğini, tüm bu karakterler ile bahse konu gemi hiyerarşisinin gerçekte de var olduğunu ve burada mevcut "sosyolojik yapı ile hiyerarşiyi didaktik olmadan anlatmaya çalıştığını" ifade eder (Karaçelik, 2015b). Filmde dikkat edilmesi gereken diğer bir husus da, özellikle son bölüme hâkim olan metaforik anlatım üzerine kurulu sinema dilidir. Yönetmen, gemide işlerin iyice içinden çıkılmaz bir hale geldiğini simgeleyen salyangoz ve sarmaşık gibi metaforlar kullanır. Sinemada "kör göze parmak metaforlar" kullanmanın "anlamlandırmayı" doğurduğunu ve bunun da "hissi öldürdüğünü" ifade eden yönetmen Karaçelik, "farklı anlamlara çıkabilecek" metaforlar kullanarak "gerçeklik duygusunu kaybetmeyi" amaçladığını ve "esas yaratmak istediği şeyin his ve gerginlik" olduğunu ifade eder (Karaçelik, 2015b).

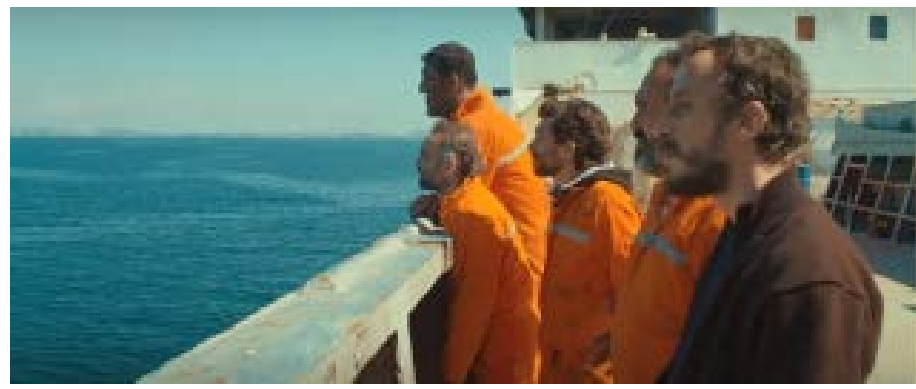

Şekil 3: Beybaba hariç gemide kalan 5 kişi (Önden arkaya: Nadir, İsmail, Alper, Cenk ve Kürt) (Kaynak: http://www.vizyonfilmizle.com.tr/39540-sarmasik-2015-yerli-film-izle.html)

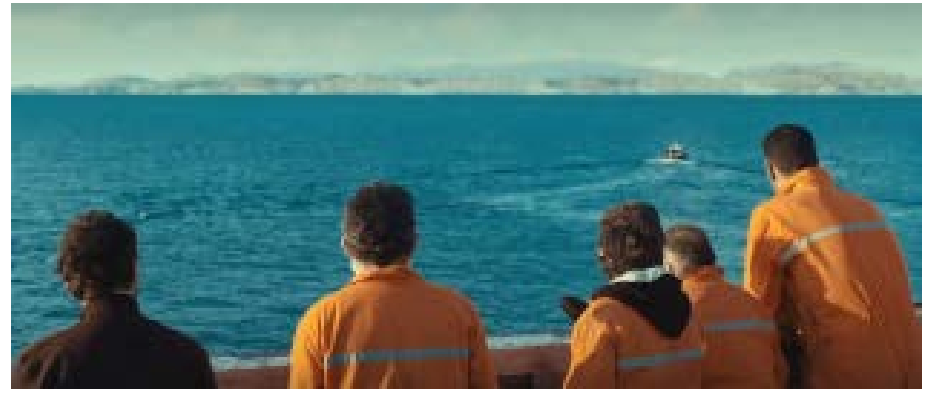

Şekil 4: Diğer mürettebatın gemiden ayrıışı (Kaynak:

http://www.vizyonfilmizle.com.tr/39540-sarmasik-2015-yerli-film-izle.html) 


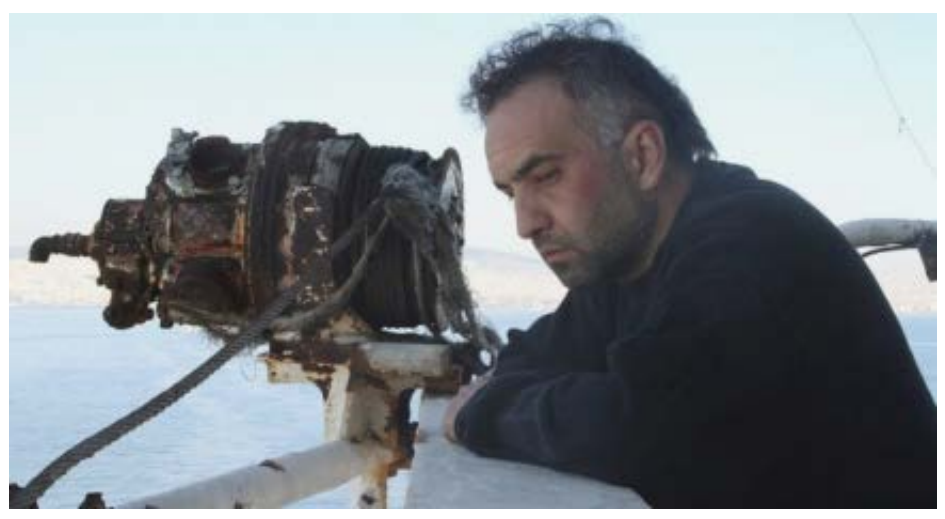

Şekil 5: Filmin ana karakteri Cenk

(Kaynak: http://ekrandedektifi.com/sarmasik-ayni-geminin-insanlari/)

Filmin iktidar ilişkileri üzerine odaklanması ise, yönetmenin toplumsal gelişmelerden etkilenmesinin bir uzantısıdır. Filmini, "İktidarı inceleyen ve ortaya koyan; o gergin ve baskıcı ortamın beni çekmeye zorladığı bir filmdir" şeklinde ifade eden yönetmen, bu etkileşimin bir yansıması olarak güncel sosyo-politik konulara ilişkin pek çok göndermeye filminde yer verir (Karaçelik, 2015a). Bu noktada, politik sinema özellikleri barındırdığı görülen filmde, bireysel psikoloji ve ilişkilere eğilen ve izleyiciyi karakterlerle özdeşleşme düşüncesine sevk eden bir sinema dili göze çarpar. "Yönetmenin yarattığı mikro dünyanın, hepimizin içerisinde yaşadığı makro dünyanın temel toplumsal çelişkilerini yansıtan bir ayna"sı niteliğine belli ölçüde haiz olması, filmi ister istemez politik sinema eksenine de çeker (Gönülşelen, 2015). Bu noktada, "filmlerin herhangi bir durumu yansıtmaktan çok, o durumun tasarlanan belli bir biçimini oluşturmak üzere seçilmiş ve birleştirilmiş temsili öğeler yoluyla birtakım tezler ileri sürdüğünü" ve "politik anlamlarını da daha çok içerdikleri tezlerde, kullanılan somut temsil stratejilerinde ve yarattıkları muhtemel etkilerde aramanın gerekliliğini" ifade etmek gerekir (Ryan \& Kellner, 2010, s. 18-19). ${ }^{3}$ Bu bağlamda, Sarmaşık'ın içerdiği karakterlerin toplumsal katman ve konuları yansıtan temsili yönler barındırması ve hikâyesinin güncel sosyo-politiğe dair göndermeler içermesi, onun bir politik sinema örneği olarak da değerlendirilmesini gerekli kılar.

\section{IKTIDAR ILIŞKILERI VE SARMAŞIK FILMI}

Sarmaşık, belirli bir politik konuya odaklanan bir film olmasa da, "Türkiye'de yaşanan toplumsal/tarihsel süreçlere ilişkin hegemonik söylemin sunduğu bakış açısının dışında görme/düşünme biçimleri edinmeye" ve "izleyiciyi ezberini bozmaya yöneltmesi nedeniyle "yeni politik sinema" kategorisinde değerlendirilebilecek bir filmdir (Suner, 2006, s. 289). "Yeni politik sinema" kavramı, "1990lardan itibaren yaşanmakta olan toplumsal ve siyasal dönüşümün bir sonucu olan, politik olayları konu almanın ötesinde ortak bir sinema anlayışı ya da eleştiri tavrı içermeyen, tematik olarak temel meselesi doğrudan aidiyet ve kimlik sorunsalı olan ve nesnel ve dışarıdan bakan bir temsil anlayışı yerine öznelliğe, öznel algı ve deneyime vurgu yapan" filmleri tanımlamak üzere kullanılır (Suner, 2006, s. 255-257). Bu çerçevede Sarmaşık da, 1990lı yıllarda çekilen Işıklar Sönmesin (Reis Çelik, 1996) ve Hoşçakal Yarın (Reis Çelik, 1998) gibi filmlerle başlayıp 2000li yıllarda Filler ve Çimen (Derviş Zaim, 2001), Hiçbir Yerde (Tayfun Pirselimoğlu, 2002) ve Yazı Tura (Uğur Yücel, 2004) gibi filmlerle devam eden ve son dönemlerde çekilen Tepenin Ardı (Emin Alper, 2012) ve Abluka (Emin Alper, 2015) filmleriyle günümüze kadar gelen politik sinema örneklerine benzeyen bir "yeni

\footnotetext{
3 Filmler toplumsal yaşamın söylem biçimlerini (biçim, figür ve temsillerini) şifreleyerek sinemasal anlatılar biçiminde aktarılar. (Ryan \& Kellner, 2010, s. 18-35).
} 
politik sinema" örneğidir. ${ }^{4}$ Zira Sarmaşık da, iktidar ve hiyerarşi gibi olguların değişen koşul ve roller çerçevesinde geçirdiği evreleri mercek altına alırken politik temalara eğilen ve aidiyet ile öznellik gibi kavramlara vurgu yapan bir sinema dili kullanır.

Bu noktada, "yeni politik sinema" kavramı ekseninde Sarmaşık'la benzerlikler arz eden; onunla çok yakın dönemlerde ve her ikisi de aynı yönetmen eliyle çekilmiş olan Tepenin Ardı (2012) ve Abluka (2015) filmlerini de içeren karşılaştırmalı bir film okuması üzerinden ilerlemek yararlı olabilir. Tepenin Ardı, toplumsal hayattan uzak bir ortamda yaşayan Faik'i, iki torunu ve oğlunun ziyaret etmesi sonrasında gelişen ve "militarizm, erkeklik, bir süreç olarak 'öteki'nin nasıl kurulduğu ve cemaat-aile ilişkileri" gibi konulara el atan bir filmdir (Konuşlu, 2013). Bir yandan, aile içi erkeklerin büyükbabaya paradoksal bir şekilde duydukları ezilme ve hayranlık duyguları ekseninde erkeklik kültürünü mercek altına alan; öbür taraftan da "silaha meraklı küçük torun ve Güneydoğu'da yaptığı askerliğin travmalarını atlatamayan" büyük torun olgularının katkısıyla Kürt sorunu ve militarizm konularını işleyen filmin merkez temasını ise "düşman yaratma" ve "ötekileştirme" olguları oluşturur (Ercivan, 2013). Tepenin Ardı, içerdiği karakterlerin toplumsal hayatta karşılıkları düşünülerek seçilmiş olması, mevcut sosyo-politik sorunlara temas etmesi ve "ötekileştirme" ile erkeklik gibi konulara değinmesi itibarıyla Sarmaşık'la benzerlikler arz eden bir "yeni politik sinema" örneğidir. Öte yandan, Tepenin Ardı'nda "ötekileştirme" ve "düşmanlaştırma" kavramları filmin merkezinde yer almakta iken, Sarmaşık'ta ise iktidar ilişkileri konusu filmin ana inceleme sahasını oluşturur.

Yönetmeni Emin Alper tarafından "politik psikolojik gerilim" olarak tanımlanan Abluka filmi ise, "iki kardeşin hikâyesi etrafında" geçen ve "gerçekle kurmacayı" bir araya getirerek distopik bir atmosfer yaratan bir filmdir (Alper, 2015). Kaotik ve karanlık bir evrenin yaratıldığı film, bizi "kıstırımışlık ve yoğun baskı üreten bir abluka ortamında normalini kaybetmiş karakterlerle tanıştırır." (Irmak, 2015) İki kardeş özelinde karakterlerin "geçirdikleri psikolojik değişim/dağılma"; yani bir anlamda yaşadıkları "psikolojik abluka durumu" ise mahalle ölçeğinde gerçekleşen fiziksel abluka durumunun mikro düzeyde de yaşandığını gösterir." (Irmak, 2015) ${ }^{5}$ Öte yandan filmde, köpeklerin belediye tarafından öldürülmesinin istenmesi ya da çöplerin yakılması hususlarında görüldüğü üzere toplumsal konulara dair göndermeler yer alır. Bu anlatılanlar çerçevesinde Sarmaşık ve Abluka arasındaki en can alıcı benzerlik ise, her iki filmin de "otoriteyi sorgulayamamış ve onun mağduru olmuş küçük insan"ların hikâyelerini anlatıyor olmasıdır (Acaroğlu \& Günerbüyük, 2015). Farklı biçimlerde de olsa her iki film de, baskı ve otoritenin etkin olduğu ortamlarda geçmesi, içinden çıkılamayan kaotik atmosferler içerisinde ilerlemesi ve insanların gerçeklerle bağlarını yitirerek psikolojik anlamda değişim yaşamaları itibarıyla pek çok ortak yön barındırırlar. Öte yandan, Sarmaşık filmi ile gerek Tepenin Ardı, gerek de Abluka filmleri arasında sinematografi, kurgu ve mekân gibi sinematik unsurlar bağlamında çok ciddi benzerlikler göze çarpmaz.

Sarmaşık filmini, iktidarın evreleri üzerine bir inceleme yapma düşüncesi üzerine şekillendiren yönetmen Karaçelik'in filmine mekân olarak bir yük gemisi seçmiş olması tesadüfî değildir. Zira yük gemilerinde egemen olan hiyerarşik yapı ile çeşitli toplumsal kurumlar içerisinde süregelen iktidar ilişkilerinin teorik ve pratik yönlerden benzerlikler arz ettiği görülür. "Seyir halinde bir gemide, yönetenler ile yönetilenler arasında net bir

\footnotetext{
${ }^{4}$ Bu filmlerin büyük bölümü anlatım özellikleri itibarıyla Türk Sineması'nın özellikle 1970lerde belirginlik kazanan toplumcu gerçekçi temsil anlayışıyla, politik hiciv geleneğiyle ve toplumsal sorunlar karşısında takındığı "hümanist" yaklaşımla süreklilik göstermektedir (Suner, 2006, s. 255).

${ }^{5}$ Bu bir yandan iki kardeş hikâyesi. İşin politik tarafı çok ön plana çıkıyor. Filmi bu nedenle 'politik psikolojik gerilim' diye tarif ediyorum. (Acaroğlu \& Günerbüyük, 2015)
} 
katmanlaşmanın" olduğu, "herkesin bir altıyla konuştuğu ve hiyerarşinin en üstündeki kişinin en alttakilerle temasa geçmediği", hatta "yüzünü bile nadir gördüğü çok sert bir hiyerarşi” gözlemlenir (Gönülşelen, 2015). Filmin ilk bölümünde, kaptan Beybaba'nın yemeğe gelişi esnasında çalışanların ayağa kalkığı ve üst kademede olan birinin yemekte Alper'i yanına çağırdığında onun askeri nizamı andırır bir şekilde durarak cevap verdiği sahnelerle bu hiyerarşi izleyiciye aktarılır. Ancak filmde geminin durması ile birlikte ortaya çıkan yeni durum sonrasında bu hiyerarşik strüktür ve Beybaba'nın iktidarı bir anda anlamını yitirir. Hikâyesini, iktidarın bu durum değişikliği sonrası geçirdiği evreleri anlama düşüncesi üzerine kuran yönetmen, filmini şu cümlelerle özetler; "İşlevini kaybetmiş bir otorite hiyerarşiyi devam ettirmek için neler yapar ya da göze alır ve hangi evrelerden geçer. Gemi artık gitmiyorsa gemi değildir. Peki, o zaman kaptanla biz ne yapacağız?" (Karaçelik, 2015b). Bu bağlamda yönetmen, iktidarın "otoritesini kaybettiğini anladığı anda tekrar kontrolü almak için neler yaptığını ve karşısında yer alan karakterlerin de bu değişime verdiği fiziksel ve duygusal tepkileri ve yaşadıkları kırılmaları görmeyi amaçladığını" ifade eder (Karaçelik, 2015b).

Filmde iktidarın evrelerini yönetenler ve yönetilenler üzerinden anlamaya dair yapılacak bir okumada ilk ele alınması gereken karakter, hikâyenin ilerleyişinde en belirleyici unsur olan kaptan Beybaba'dır. Geminin durması sonrasında, iktidarın doğası gereği otoritesini sürdürmek isteyen Beybaba, bunu başarmak için film boyunca çeşitli yollar dener. Bu çerçevede, mürettebat üzerinde ilk olarak muhbirliğe dayalı, daha esnek bir yönetim sergileyen Beybaba, zaman içerisinde otoritesinin sarsıldığını görünce, önceki durumla çelişir bir şekilde daha sert, dışlayıcı ve insanları birbirine düşürmeye çalışan bir yönetime geçiş yapar. ${ }^{6}$ Örneğin, geminin durması sonrasında asgari yaşam gereksinimlerinin karşılanamaz hale geldiği bir ortamda bile, Cenk tarafından kendisine jest olarak gönderilen sucuğu otoritesini sarstığını düşündüğü için sert bir tepki ile reddeden Beybaba, durumun gerektirdiği insani yaklaşımı sergilemek yerine; bunu daha baskıcı bir yönetim biçimine geçiş için gerekçe olarak kullanır. Dolayısıyla kendi varlığını sürdürebilme adına; empati ve iletişime dayalı bir idare yerine, öncelikle hiyerarşinin keskin bir şekilde ve her şartta korunduğu ve sadece onun izin verdiği ölçüde bir diyaloga prim verir. Bunun yanında, iktidar gücü azalan Beybaba; örneklerini hiyerarşinin en katı uygulandığı yerlerden biri olan hapishanelerde gördüğümüz "statü tahakkümü" yolunu da devreye sokar ve tüm mürettebatı karşısına dizerek "küfretme, tehdit" ve alçaltma gibi tahakküm biçimleriyle otoritesini geri kazanma yolunu dener (Öztürk, 2012, s.171) (Şekil 6). Bu yollarla, Foucault'un da ifade ettiği üzere "disipliner iktidarın terbiye etme" görevini yerine getiren Beybaba, esas itibarıyla mürettebatı "disipline ve terbiye etme" ve "itaatini' sağlama amacını güder (Foucault, 2006). Otoriteyi bu yollarla sağlama girişimlerinin sonuçsuz kalması neticesinde Beybaba, filmin son kısmında her yeri saran sarmaşıklarla da simgelendiği üzere, zirveye çıkan kaos ve paranoya ortamına çözüm bulamayarak uzaklaşır ve kendini izole eder. ${ }^{7}$ (Şekil 7)

\footnotetext{
${ }^{6}$ Cenk'le yaşadığı tartışmayı Beybaba'ya taşıyan ve Cenk'in üstüne yürüdüğünü söyleyen İsmail'e, Beybaba'nın "üstlerine varma, birkaç gün rahat bırak" dediği sahnede de görüldüğü üzere Beybaba'nın ilk etapta daha yumuşak bir iktidar dilini tercih ettiğini görürüz.

7 Örneğin filmin sonlarına doğru Beybaba, gece yattığı odanın kapısının önünde, içeri girmeden gölgesiyle kendisine görünerek bir tür psikolojik tehdit gerçekleştiren insandan korkar, ancak hiçbir tepki vermez.
} 


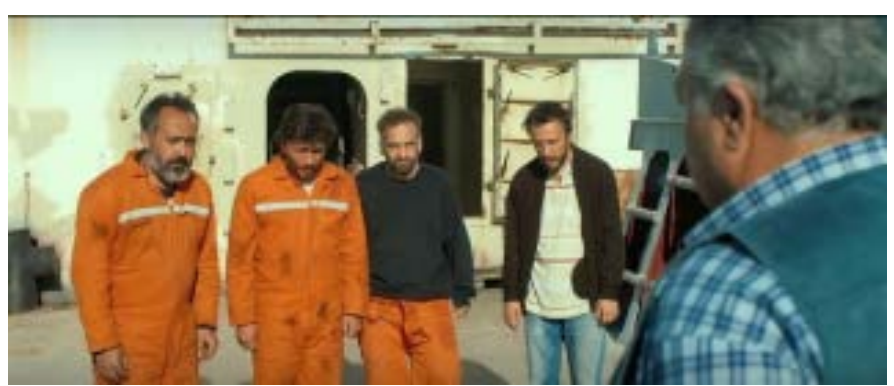

Şekil 6: Otoritesinin sarsıldığını düşünen Beybaba; küfür, alçaltma ve sertlik yollarıyla gücünü geri kazanmaya çalışır. (Kaynak: http://www.vizyonfilmizle.com.tr/39540-sarmasik-2015-yerlifilm-izle.html)

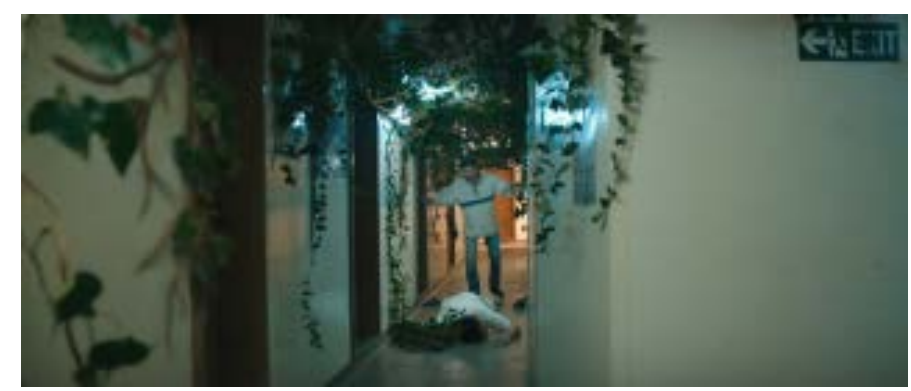

Şekil 7: İsmail'in yarılan kafasından çıkan sarmaşık, gemide her yeri saran kaos ve paranoya atmosferini simgeler. (Kaynak: http://www.vizyonfilmizle.com.tr/39540-sarmasik-2015-yerli-filmizle.html)

Gemideki diğer bir iktidar aygıtı, Beybaba'ya muhbirlik yapan ve onun gemideki otoritesini mürettebata aktarma işlevini gören İsmail karakteridir. Filmin sonuna kadar Beybaba'ya sorgusuz sualsiz itaat eden ve zaman zaman onun otoritesinden rol devşiren bir profil çizen İsmail, gemide Beybaba'nın iktidarının devamlıı̆ını sağlamak için de elinden geleni yapar. Bu yönleriyle, Adorno'nun ifade ettiği (2003, s. 300-306) ve otoriter kişiliğin temel niteliğini oluşturan "çift değerlilik özelliğini" barındıran İsmail; tarihte ve günümüzde de çeşitli karşılıkları olan "kendisinden daha güçlü bir otoriteye koşulsuz boyun eğme ve daha zayıf olanı ezme" tavrını sergiler. ${ }^{8}$ Beybaba'nın iktidarına karşı en sert tepkiyi gösteren kişiyse Cenk'tir. Geminin demirlemesi sonrasında ortaya çıkan zor koşullar nedeniyle gittikçe paranoyaklaşan Cenk, Alper'le birlikte iktidarla gerginlik dozu film boyunca yükselen bir çatışma sürdürür. (Şekil 8) İktidara karşı isyanın ilk fitilini de, İsmail'in kendisine verdiği "güverteyi yıka" talimatına, hiyerarşinin anlamsızlaştığını düşünmesinin de etkisiyle "bana Beybaba ağzıyla konuşma" diye cevap vererek ve kendisine edilen küfür sonucu olayı kavga boyutuna vardırarak Cenk ateşler. ${ }^{9}$ (Şekil 9) Öte yandan, film boyunca çoğunlukla İsmail üzerinden yürütülen bu tepki verme ve başkaldırı hali, iktidarın ana temsilcisi olan Beybaba'ya pek yansımaz. Beybaba'ya, sadece mürettebatı sert bir şekilde azarlaması sonrasında arkasını dönüp giderken, vurma hedefi olmadan arkasından atılan bir çekiç yoluyla somut bir tepki gösterilir ki; bu da Beybaba'nın arkasını döndüğünde kimsenin çekici ben attım dememesi ve Cenk'e verilen "çekici çantaya koy" emrinin onun tarafından yerine getirilmesiyle son bulur. Söz konusu iktidar tahakkümünün film

\footnotetext{
8 “Adorno'ya göre, otoritaryen karakterin kuvvetle özdeşleşmesi, 'aşağı' olan her şeyin yadsınmasıyla birlikte gider. Otoritaryen karakter, bütün iç grupla ve aileyle özdeşleşerek otoriter disiplini kendi kendine dayatabilmektedir." (Oktan, 2008, s. 152-166)

${ }^{9}$ Cenk'in isyankâr yönü, futbol dünyasında benzer bir kimlik taşıyan Adana Demirspor formasını giymesi ve ona ait olan 'Şimşekler' tezahüratını yapması yoluyla sembolik olarak izleyiciye aktarıır.
} 
boyunca aşılamaması halinin, başta Cenk olmak üzere tüm mürettebat nezdinde bir tür kaotik kabullenmişlik psikolojisi doğurduğu; bunun da filmin sonunda zirveye çıkan ve tüm gemiye sirayet eden bir çaresizlik ve bunalım haline sebebiyet verdiği görülür. Esasen filmin sonunda İsmail'in yarılan kafasından çıkarak her yeri saran sarmaşıklar da bir metafor olarak bu çaresizlik ve çözümsüzlük duygusunun tüm gemiyi sarmasını simgeler. Salyangoz metaforu da benzer bir şekilde, Kürt'ün ortadan kaybolması ve gemide işlerin iyice sarpa sarması sürecinde ortaya çıkan ve filmin sonunda tam bir kaos halinin doğması ile birlikte geminin güvertesini kaplayan bir tür "lanet" durumunu imler. ${ }^{10}$ (Şekil 10)

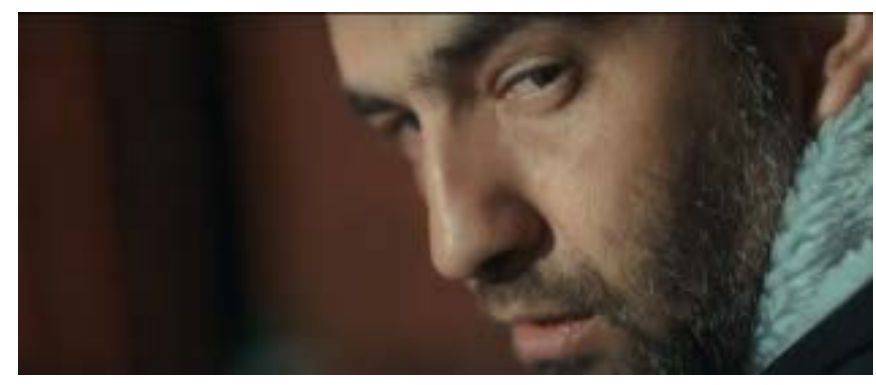

Şekil 8: Cenk'in filmin sonunda zirveye çıkan bunalım ve kontrolden çıkma hali (Kaynak: http://www.vizyonfilmizle.com.tr/39540-sarmasik-2015-yerli-film-izle.html)

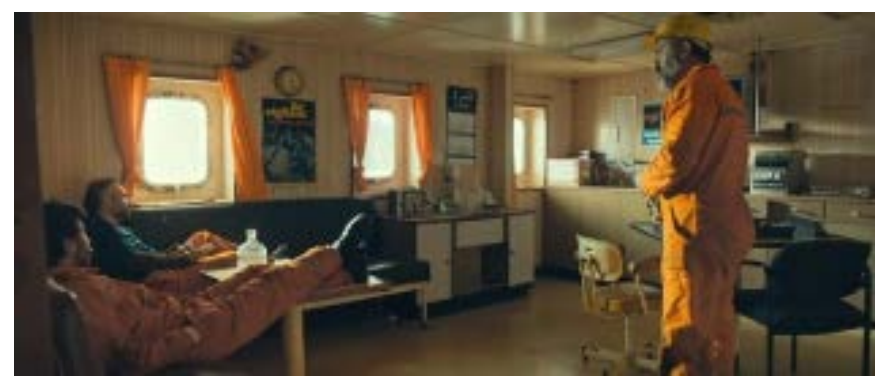

Şekil 9: İktidara karşı ilk tepkinin, Cenk'in İsmail'e "bana Beybaba ağzıyla konuşma" deyişiyle verildiği sahne (Kaynak: http://www.vizyonfilmizle.com.tr/39540-sarmasik-2015-yerli-filmizle.html)

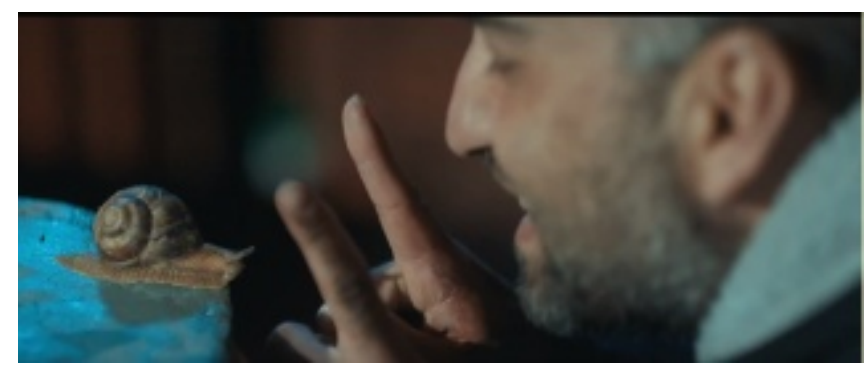

Şekil 10: Salyangoz Metaforu (Kaynak: http://www.vizyonfilmizle.com.tr/39540-sarmasik-2015yerli-film-izle.html)

İktidar ilişkileri bağlamında bulunduğu yerin belirleyici bir rolü olması nedeniyle irdelenmesi gereken diğer bir karakter de, filmin bir noktasında ortadan kaybolan ve sonrasında hayalet gibi zaman zaman görünmeye devam ederek, hem varlığı hem de

\footnotetext{
10 “Yaşlı Gemici'nin Albatros'u öldürmesiyle Cenk'in Kürt'ü öldürmesi birbiriyle bağdaşıyor. Gemiyi saran lanet ise o an başlıyor. Lanetin başlama zamanıyla neredeyse paralel ilerleyen 'salyangoz metaforu' psikolojik gel-gitlerin zirve noktasına ulaştığı anda yadsınamayacak duruma geliyor." (Durmaz, 2015)
} 
yokluğuyla herkes üzerindeki etkisi film boyunca devam eden Kürt figürüdür. Kendisine, gündemde olan toplumsal bir soruna dair temsili bir kimlik de biçilen bu figür, filmde de gerçek hayatta olduğu gibi çözülemeyen ve bu yönüyle de süregelen iktidar mücadelesinin kaderini tayin edebilecek derecede belirleyici olabilen bir soruna karşılık gelir. Filmin ana unsurlarından biri olan Kürt figürü, filmde politik bağlamın en görünür hale geldiği karakter olma hüviyetini taşır. Netice itibarıyla filmin sonuna kadar kırılamayan iktidar hegemonyası ise son sahnede Cenk'in İsmail'e sorduğu "Beybaba'nın anahtarı sende mi?" sorusuna kadar sürerken; soruya cevaben İsmail'in bakışı ile birlikte o andan itibaren ortaya çıkması muhtemel bir ortak hareket etme ve tepki verme halinin işareti verilerek, yönetmen penceresinden duruma nasıl yaklaşılması gerektiğine dair bir yorumla film sonlandırılır.

\section{SARMAŞIK FILMI'NDE ERKEKLIK VE IKTTIDAR ILIŞKISI}

Sarmaşık, iktidarın geçirebildiği evreler ve bunun insan psikolojisi üzerindeki etkilerini inceleme düşüncesi üzerine kurulu bir film olmakla beraber, 1980'lerden itibaren Türk Sineması'nda artış gösteren ve erkek merkezli konular ile erkek dünyasına dair yaşam biçimleri üzerine odaklanan filmlerle de benzerlikler arz eden yönler barındırır. ${ }^{11}$ Tamamen erkeklerden oluşan ve erkek mekânlar ve ilişkiler barındıran bir yük gemisinde geçen bu filmde, bahse konu iktidar mücadelesini etkileyen ve "erkekler arasındaki ilişkileri kontrol eden ataerkil bir düzen" göze çarpar" (Arık, 2009, s.194). "Kendisini 'kadın olmamak' üzerinden tanımlayan bireylerin oluşturduğu homososyal bir topluluk" olan gemi mürettebatı, "kendine has hiyerarşik bir yapıya sadık kalarak geliştirdiği muhabbetler üzerinden" ister istemez bir "hegemonik erkeklik" dünyası inşa eder (Umut, 2007). ${ }^{12}$ Bu bağlamda filmde, "hegemonik erkeklik" özellikleri gösteren davranış biçimlerinin egemen olduğu (küfür, şiddet vs.) bir gemi ortamı söz konusudur. Burada "hegemonik erkeklik" kavramı, "erkeğin cinsiyet temelindeki statüsünün, kendi cinsiyetindeki bireylerle arasında kurduğu ilişkide belirleyici bir kategori"ye karşılık gelir (Connell, 1998). ${ }^{13}$ "Hegemonik erkeklik" daima kadınlarla ilgili olduğu kadar, ikincil konuma itilmiş çeşitli erkeklik biçimleriyle ilgili olarak da inşa edilmektedir. Farklı erkeklik biçimleri arasındaki etkileşim, ataerkil bir toplumsal düzenin işleyiş biçiminin ayrılmaz bir parçasıdır" (Connell, 1998, s. 245). Dolayısıyla, film üzerinden konuyu ele alma noktasında, "sadece kadınlığa karşı egemenlik addeden pratikleri değil, erkekliğin çoklu bir tanım kapsamında farklı türde erkeklikler karşısındaki hallerini görme" düşüncesini içeren bir yaklaşımın esas alınması gerekir (Arık, 2009, s. 185). Zira "tek tip bir erkeklik yoktur; her biri gücün farklı pozisyonlarıyla iç içe geçmiş farklı pek çok erkeklik vardır." (Connell, 2005) Elbette ki gemi hiyerarşisi ve iktidar aygıtlarının filmin son sahnesine kadar asli etken olduğu bir ortam söz konusudur. Ancak, "Kiesling'in de dediği gibi erkekliği anlamak için başlangıç noktasının, erkek-kadın karşıtlığından öte, erkekler arasında uygulanan asimetrik egemenlik ve itibar unsurlarının analizi" (1997, s. 65-86) olduğu düşünüldüğünde, filmde erkekliğe dair unsurlar ile iktidar ilişkilerinin bir arada olduğu ve hatta karşılıklı olarak birbirini etkilediği durumlar karşımıza çıkar. (Arık, 2009, s. 185)

Bu noktada, Sarmaşık filmi gibi gemide geçmesi, erkeklik olgusunu Sarmaşık filmine göre daha merkezde incelemesi ve bu yönleriyle de bize karşılaştırmalı okuma imkânı sunabilmesi nedenleriyle 1998 yılı yapımı Gemide (Serdar Akar) filmine ayrı bir parantez açmak gerekir. Yönetmen Karaçelik, "kendi filminde iktidar veya kişilerin psikolojik çöküşünün erkekliklerinden daha önde olduğunu" ve "Gemide'de geminin

\footnotetext{
${ }^{11}$ Bu dönemde çekilen ve gergin, bunalımlı ve kırılganlıkları olan erkek hikâyeleri anlatan filmlerden bazıları Gemide (Serdar Akar-1998), Yazı-Tura (2004 - Uğur Yücel) ve Çoğunluk'tur (Yüce, 2010).

12 "Hegemonik erkekliğin inşasında zorunlu bir durak olarak görülen homososyalliğin en önemli özelliği kadınlardan izole bir ortamı gerektirmesidir (Yiğit, 2015).

13 "Hegemonik erkeklik kavramıyla anlatılmak istenen, iktidarın kültürel kodlarla özel alanın da içine girerek toplumsal yapıda meşruluk kazanmasıdır." (Taşıtman, 2012, s. 126).
} 
sığınılacak bir mekân iken, Sarmaşık'ta hapishane" haline dönüştüğünü ifade ederek iki filmin birbirinden farklı olduğunun altını çizer (Karaçelik, 2016). Ancak her iki filmin de; Gemide'nin giriş sahnesinde ifade edilen "Bir memleket gibidir gemi. Her şey düzenli ve kontrol altında olmalıdır. Kaidelere uyulmalıdır, kanunlara, nizamlara.." ifadelerine uyan gemilerde geçmesi ve birçoğu kendi gerçekliklerinden kaçan ya da gidecek yerleri olmayan karakterlerden oluşması, aralarında ciddi benzerlikler olduğuna işaret eden durumlardır. Gemide, 4 kişilik bir mürettebattan oluşan ve "Laleli'de demirli halde bulunan bir kum kosterinde geçen"; "cinayet, hırsızlık, tecavüz, içicilik ve bolca erkek muhabbeti içeren; memlekete, İstanbul'a ve erkekliğe dair" bir filmdir" (Günerbüyük, 2015). Filmi tanımlayan başlıklar bile esas itibarıyla 'cinsiyet' ve 'erkeklik' temalarının hikâyede kapladığı yer hakkında fikir verir. Karakterler arasında farklı hegemonik erkeklik kategorizasyonlarının gözlemlenmesi ve "hikâyenin neredeyse tamamının geçtiği gemi" örneğinde görüldüğü üzere homososyal ortamların vurgulanması gibi unsurlar yoluyla filmde erkeklik olgusuna çeşitli pencerelerden bakılır (Yiğit, 2015). Öte yandan filmde, Sarmaşık'ta da olduğu üzere, toplumsal hayatta mevcut sorunların eleştirildiği ve gerçek hayatta vuku bulan olaylara benzeyen durumların anlatıldığı bir sinema dili gözlemlenir. Gemi mekânlarının kasvetli atmosferi ile kaptanların otoritesinin süreç içerisinde azalıyor olması üzerine ilerleyen hikâyeler de filmlerin diğer ortak yanlarıdır. İki film arasındaki en temel fark ise, Gemide'nin ağırlıklı olarak politik olmayan ve erkeklik başta olmak üzere farklı toplumsal sorunlara eğilen bir anlatıyı tercih etmesi; Sarmaşık'n ise erkekliği arkada bırakan bir iktidar incelemesi ve politik sinema anlayışına yönelmesidir.

Sarmaşık filminin geçtiği gemide, erkek egemen toplumsal yaşantıda görüldüğü üzere iktidar ilişkileri ve bireylerarası iletişim genellikle erkek dili ve bakış açısıyla ifade bulur. Otorite ve iktidar mücadelesi, ataerkil toplum reflekslerinin de bir uzantısı olarak fazlasıyla erildir. Öte yandan filmde, "Gramsci'nin hegemonik erkeklik olarak adlandırdığı erilliğin sadece kadınlar için değil erkekler arasındaki hiyerarşiyi de düzenleyen yapısının ortak bir konsensüsle sürekli yaşatılması" hali de kısmen gözlemlenir (Elmacı, 2013, s. 265). Dolayısıyla, her ne kadar altı erkekten oluşan bu gemide hiyerarşi ve 'erk' ön planda olsa da, yazının başlığında da ironik bir şekilde vurgulandığı üzere 'erk'in dışavurumu fazlasıyla 'erkek'tir ve 'erk'i elde etmek için 'erkekçe' davranmak gerekir. "İktidar dili olarak erkeklik dayatmasından doğrudan etkilenen kadınların dışında, (belki) doğrudan değil ama 'içeriden' biri olmaları sebebiyle bizzat erkekler de nasibini alır." Çünkü "erkeklik sürekli olarak ve yeniden kazanılması gereken bir şeydir" ve filmdeki karakterler arasında süregelen iktidar çatışmalarında bu tip mücadeleler sıklıkla karşımıza çıkar (Taşıtman, 2012, s. 126). Bunun yanında filmde, gemide işleyen normal düzen üzerinde de oldukça etkisi olan "hegemonik erkeklik" eksenli bir dünya anlatılması ve diyaloglara erkek bir dilin hâkim olması (örneğin küfürlü diyaloglara sıkça yer verilmesi) gibi direkt olarak erkeklik kodlarına referans veren bir sinema dilinin de varlığı görülür. Bu dil ile erkekliğin vurgulanması ya da onu merkeze alan bir düşünsel yaklaşımın öne sürülmesinden ziyade karakterlerin gerginliği, sıkıntıları ve hapsolma halleri gibi etkenlerin, onların üzerindeki psikolojik etkilerini dışa vurma amacının güdüldüğü ifade edilmelidir. (Şekil 11) 


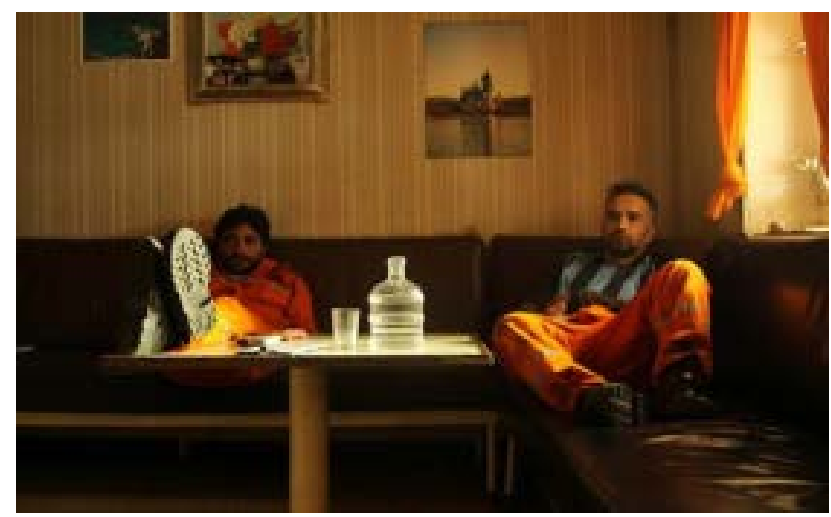

Şekil 11: Zaman geçtikçe ve gemi durdukça sıkıntı ve gerilim artar (Kaynak:http://bianet.org/biamag/sanat/170045-sarmasik-bir-cenk-hikayesi)

Bu çerçevede, bahse konu alt metnin özellikle İsmail ile Cenk arasındaki emir komuta zinciri kaynaklı çekişmelerde su yüzüne çıktığını görülür. Zira Cenk, İsmail üzerinden kendisine iletilen iktidar tahakkümüne küfür, tehdit ve şiddet gibi erkekliğe ait hegemonya araçları yoluyla cevap vererek, anlamını yitirdiğini düşündüğü bir otoritenin kendisine dayatılmasına direnç gösterir. Aralarındaki çekişmenin asıl sebebi, İsmail tarafından Cenk'e dayatılan otorite olsa da, buna verilen fiziksel tepkinin kıvılcımını ateşleyen asıl unsur ise İsmail tarafından Cenk'e edilen ve Türk 'erkek' merkezli bakış açısında çok önemli bir gerilim sebebi olan bir küfür olur. İsmail'in bu küfürü, kendisine yansıtılan tepkinin en belirgin sebebi gibi görünmekle birlikte; aslında iki karakter arasında yürüyen keskin hiyerarşik çatışmanın kavgaya dönüşmesinde bir bahane işlevi görür. Öte yandan, İsmail de kendisine erkek diliyle verilen bu tepkiye benzer bir dille cevap verir; ancak yine de filmin sonuna kadar iktidar olma kaynaklı gücünü, bu erkeklik eksenli çekişme dilinin önüne koyarak hareket eder. Bunun yanında Beybaba da otoritesini kaybetmeye başlayınca, iktidar gücü yanında, erkek dünyasının unsurları olan küfür ve şiddet (Ör: Cenk'e tokat attığı ve mürettebata küfürlü konuşma yaptığı sahne) yollarını kullanmaya başlayarak, tekrar otoritesini geri kazanma amacını güder. Zira iktidar gücünü pekiştirmek için erkekliğe de intiyaç doğmuştur ve "erkekliğe ilişkin en önemli göstergelerden biri şiddetin bizzat eril özne tarafından sunumudur" (Elmacı, 2013, s. 266). Beybabanın asıl amacı, gemide var olan erkek ortamında ve ataerkil erkek psikolojisi üzerinde güçlü bir etkisi olduğunu bildiği şiddet ve bastırma dilini kullanarak, gemideki iktidarını pekiştirmektir.

Erkeklik olgusunun filmde işgal ettiği yer ile hikâyenin merkezinde yer alan iktidar ve hiyerarşi olguları arasındaki ilişkiye bakıldığında; toplumsal hayatın çeşitli kesimlerinde karşılık bulan bir karakter örneklemi karşımıza çıkar. Özdaş'ın "Angst (Kaygılı) erkeklik" tanımlamasıyla örtüşen ve filmde Cenk'in temsil ettiği bir karakter yoluyla sunulan bu örneklem çerçevesinde, kendisini çoğunlukla erkeklik kodlarıyla ve yer yer delikanlılık jargonuyla ifade eden, eğitimsiz ve lümpen olabilmesinin yanında içki ve uyuşturucu da kullanabilen; öte yandan bu özelliklerle çelişen bir biçimde muhafazakar yönler de barındırabilen bir tip karşımıza çıkar. ${ }^{14}$ Toplumsal hayatta da karşımıza çıkan ve iktidar ilişkileri ile erkeklik olgusunun somut kesişim noktalarını yansıtan bu profil, yukarıda da örneklendiği üzere erkekliğe dair ve erk odaklı bazı davranış kalıpları sergileme yoluyla bir iktidar alanı yaratmayı hedeflerken; daha güçlü bir erkin kendisine yönelik benzer içerikli tahakkümüne karşı da reaksiyon üretemez ve boyun eğer.

14 Özdaş, yönetmenin filmde yaptığı en iyi şeyin, genç toplumsal erkeğin estetik damarını çok iyi yakalayabilen bir dili oturtabilmesi olduğunu ifade eder (Özdaş, 2015). 
Filmde Beybaba eliyle hayata geçirilen değişken iktidar biçimleri ve diğerlerinin buna verdiği fiziksel ve duygusal tepkiler üzerinden bir çatışma hali ilerlerken; bir yandan da iktidarın desteklenmesi ya da ona karşı direnilmesinde bir yol olarak, karakterlerin birbirlerine erkek davranışlarıyla kurmaya çalıştığı bir egemenlik ve itibar kazanma çabasının varlığı göze çarpar. Erkeklik, bu filmde merkezde yer alan belirleyici bir unsur olmaktan ziyade iktidarın kendini ifade etme ve dönüştürme girişimlerinde, alttakilerin de buna karşı mücadele ederken daha güçlü bir pozisyon elde etme çabasında kullandığı tepki dilini oluşturan önemli unsurlardan biri olarak karşımıza çıkar. Bu çerçevede, ne kadar 'erkek' olunduğu ve onun gereklerine uygun davranıldığı, gemide ne derece güçlü bir iktidara sahip olunduğunun göstergesi olmadığı gibi, bireysel çatışma ve mücadelelerde güç elde etme noktasında araçsal bir nitelik taşımanın dışında bir anlam da ifade etmez. Filmin sonlarına doğru geminin yaşanamaz bir hale gelmesinin de etkisiyle gemidekiler için ana sorun, Beybaba'nın gemide zorunlu kalınmasına sebep olarak görülmesi ve elinde tutup kimseye vermediği 'anahtar'ın istenen şeylere ulaşılmasına engel olması durumudur.

\section{SINEMATIK MEKÂN KULLANIMININ FILMDEKI YERI}

Sarmaşık filmi, esas derdinin izleyiciye aktarılması ve sinematografik çatısının oluşturulması noktasında mekân seçimi ve kullanımının getirilerinden oldukça faydalanan bir filmdir. Bu bağlamda en büyük rolü de, hiç kuşkusuz mekânsal olarak filmin tamamına yakın bir bölümünün geçtiği yük gemisi oynar. Değişen şartlarda iktidarın evrelerini anlama düşüncesi üzerine kurulu olan filmde; belli kuralların, disiplinin ve çalışmaya odaklı bir yapının egemen olduğu bir yük gemisinin kullanılmış olması, bilinçli yönlendirildiği anlaşılan bir mekânsal tercihe işaret eder. Zira yük gemileri, çalışma prensipleri ve işleyişleri ile içerisinde sürdürülen gündelik yaşam faaliyetleri itibariyle katı bir emir komuta zinciri ve hiyerarşik yapılanmanın hüküm sürdüğü mekânsal temsiliyetlerdir. Mimari yapıları itibariyle bu gemiler, içerdikleri işleve dayalı mekânsal ayrımlar (güverte, makine bölümü, vs.), dar ve dışa kapalı koridorlar ve koğuş sisteminde tasarlanan kamaraları ile denetimin, kuralların ve hiyerarşinin görünür hale geldiği soğuk ve kasvetli mekânlardır. (Şekil 12) Filmdeki yük gemisi, Beybaba'nın temsil ettiği “iktidarın yürüttüğü tahakkümün veya hegemonyanın sürmesine, sağlamlaşmasına ve güçlenmesine katkı sağlayacak bir kullanımın nesnesi olması anlamında diyalektik" bir mekândır (Öztürk, 2012, s. 27). Diğer taraftan tek ve aynı bir mekân ve otoriteden müteşekkil olması, katı kuralların hayatı belirlemesi ve belli bir düzen ve program çerçevesinde işleyen bir yapı arz etmesi itibarıyla, söz konusu yük gemisi Erving Goffman'ın "total kurum”lar olarak tanımladığı mekânlara paralellik arz eden yönler de barındırır (Goffman, 1961, s. 4-6). Ayrıca bu geminin, "çalışmak veya bazı görevleri icra edebilmek amacıyla kurulmuş olması" ve "insanların dışarıyla sosyal etkileşimine engeller getirilmesi" nedeniyle de Goffman'ın "total kurum"lar olarak kavramsallaştırdığı mekânların özelliklerini taşıdığı görülür (Öztürk, 2012, s. 131-132). ${ }^{15}$ Dolayısıyla, iktidar ve mekân ilişkisinin sinema yoluyla ele alınmasına oldukça elverişli araçtır. Yönetmenin de bu çerçevede, filmin ana mekânı olarak seçtiği geminin bahse konu özelliklerinden faydalanan bir sinema dilini tercih ettiği ve mekâna dayalı anlatımlara sıklıkla yer verdiği görülür.

\footnotetext{
${ }^{15}$ Total kurumlar hakkında ayrıntılı bilgi için bkz. (Goffman, 1961).
} 


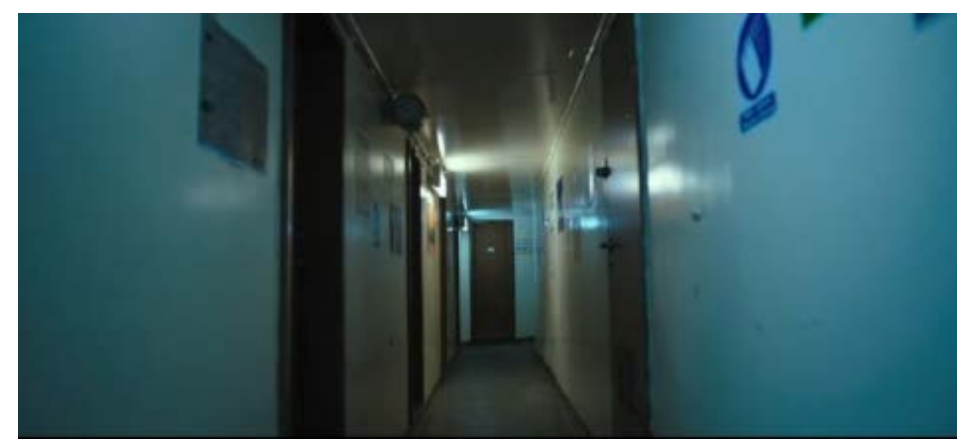

Şekil 12: Dar koridorların gösterildiği sahnelerle gemideki soğuk ve kasvetli ortam vurgulanır. (Kaynak: http://www.vizyonfilmizle.com.tr/39540-sarmasik-2015-yerli-film-izle.html)

Bu çerçevede öncelikle, filmin tek bir ana mekâna sahip olması ve bu ana mekân içerisinde yer alan sınırlı sayıda alt mekânda geçen sahnelerden oluşması nedeniyle tiyatro eseri özellikleri taşıdığının altını çizmek gerekir. ${ }^{16}$ Bunun yanında görüntü yönetimi ve kurgu gibi sinematik unsurların da katkısıyla, filmin belli bölümlerde salt bir mekân filmi hüviyetine büründüğü ve mekân ile kurulan ilişkinin sinematografide başat bir unsur haline geldiği rahatlıkla söylenebilir. Gemide kalan 6 kişide zaman içerisinde ortaya çıkan paranoyaklaşma ve bunalım hallerinin yansıtılması ve geminin hepsi için bir tür hapishaneye dönüşmesi hali de mekânın aktörleştiği çeşitli sekanslarla izleyiciye sunulur. Durması sonrasında işlevini yitirip iyice çıkışı mümkün olmayan ve "dışarıdaki toplumsal çevreden kopartılarak hapsolmayı" üreten bir mekân haline gelen yük gemisi, Foucault'un tabiriyle herkesin içinde mahsur kaldığı bir "hapishane tipi kuruma" dönüşür (Öztürk, 2012, s. 136). ${ }^{17}$ Zira bu gibi mekânları tanımlarken belirtilen "bireylerin sabit bir yere kapatılmaları, en küçük hareketlerinin bile denetlenmesi, iktidarın hiyerarşik ve sürekli bir biçimine göre hiçbir paylaşım olmadan icra edilmesi ve bütün bu unsurların bütüncül bir disiplinsel düzeneğin modelini” oluşturması hallerinin tamamı artık bu gemi için de geçerlidir (Foucault, 2006, s. 292). Bu bağlamda, söz konusu "hapishane tipi kurum" ise duvar ve parmaklıklarla değil gemi alanı ile sınırlanırken; bu sınırın devamında denizle başlayıp, özgürlüğü imleyen ve gemiden sıklıkla gösterilen karayla sonlanan hapishanenin periferisi ve özgürlüğün sınırları çeşitli kamera açıları ve mekân kullanımları yoluyla izleyiciye aktarılır.

Filmde, geminin mevcut soğuk, içe kapalı ve disipliner mekânsal yapısının etkili bir görüntü yönetimi eşliğinde vurgulanmasıyla "mekânı özneleştiren bir gerilim yaratılır."18 (Şekil 13) Örneğin, kameranın gemi güvertesi ve kamaralarda gezdirilmesi ve gemi ana mekânı ile alt mekânlarının çeşitli açılardan gösterilmesi yoluyla gemideki soğuk, mekanik ve hiyerarşik yaşantı ve mekânsal düzen izleyiciye yansıtılır. (Şekil 14) Yine kameranın boş koridorlarda sabit hızla gezdirildiği sahnelerle gemideki kasvetli ortam izleyiciye aktarıııken, Beybaba ve diğerleri arasındaki mekânsal uzaklık, erişilmezlik ve hiyerarşi farkına da gönderme yapılır. Gemide herkesin özel yaşantısını sürdürdüğü mekânlar olan kamaraların dar ve kapalı atmosferinden faydalanarak insanların bunalımlı, yalnız, sıkışmış ve çaresiz halleri ortaya konulur. Bu çerçevede kamaralarda geçen sahnelerde kullanılan yakın çekim teknikleri, mekân darlığı ve kapalılığına yapılan vurgular ve gemide hapsolma duygusunu imleyen çeşitli kamera kullanımları yoluyla mekân ve görüntü yönetimi eksenli bir hikâye anlatısı gerçekleştirilir. Filmde, geminin bir hapishane haline dönüşmesinin ve hapsolma duygusunun karakterlerdeki yansımalarının ele alındığı sahneler de vardır. İsmail'in güverteden karaya baktığı bir

\footnotetext{
${ }^{16}$ Yönetmen Karaçelik, filmini başta bir tiyatro eseri olarak yapmayı düşündüğünü de ifade eder (Yer Gösterici, 2015).

17 Hapishane tipi kurumlara ilişkin ayrıntılı bilgi için bkz. (Foucault, 2006).

18 Filmin sonunda neredeyse gemi ile özdeşlik kurulabildiğini ifade eden Özdaş, Sarmaşık'ı son dönem sinemamızın post apokaliptik mekân filmi olarak tanımlar. (Özdaş, 2015)
} 
sahnede, gemiden ayrılışın yasak olması nedeniyle karanın, yani özgürlüğün erişilmez bir noktada olması ve bu bağlamda hapsolma hali; ya da Alper'in güneşlenmek için güverteye çıktığı bir sahnede, karayı da içeren bir mekân çekimi yoluyla geminin özgürlüğün sınırı olması ve yine buradan çıkılamaması durumu vurgulanır. (Şekil 15)

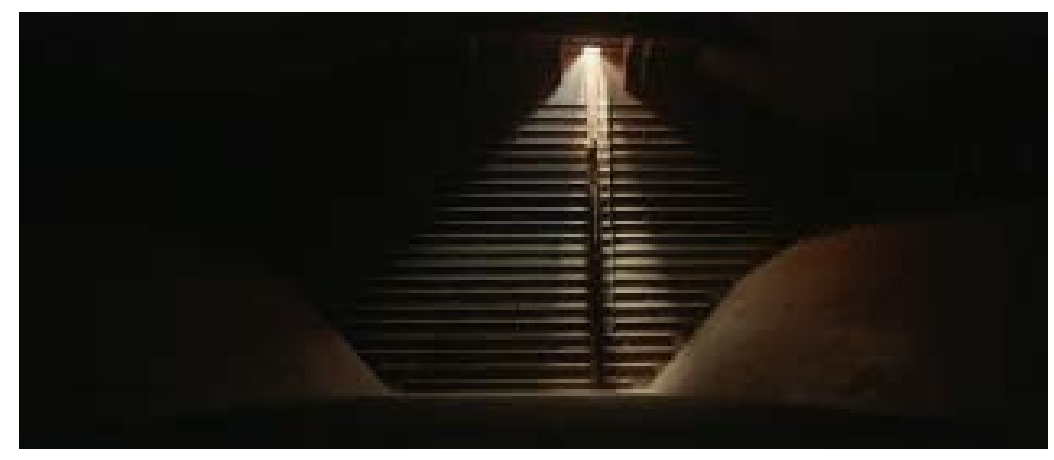

Şekil 13: Geniş ve karanlık bir mekân içerisinde Kürt'ün arandığı bir sahnede, görüntü yönetiminin de katkısıyla mekânın başrolde olduğu güçlü bir gerilim yaratııı.

(Kaynak:http://www.vizyonfilmizle.com.tr/39540-sarmasik-2015-yerli-film-izle.html)

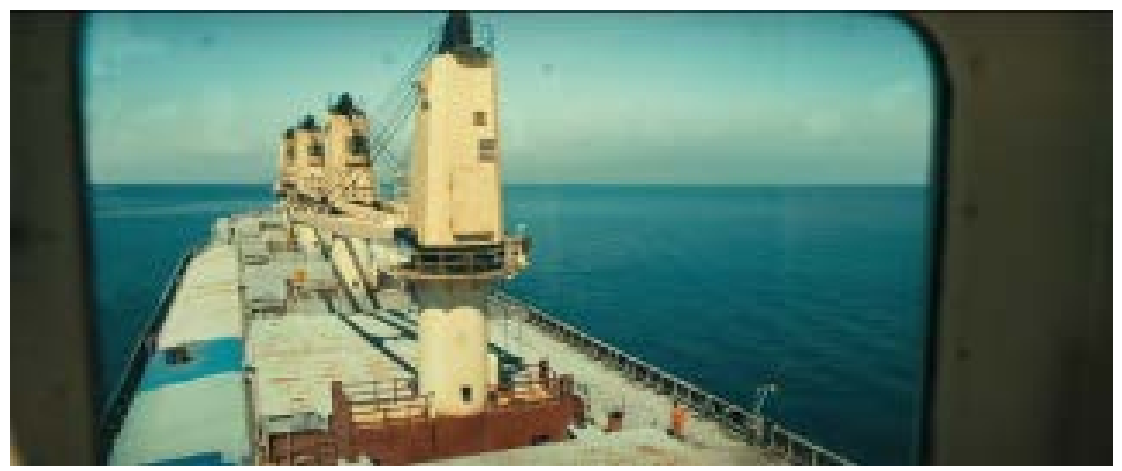

Şekil 14: Geminin mekânsal sınırları ve alt mekânları çeşitli görüntülerle izleyiciye aktarılır. (Kaynak: http://www.vizyonfilmizle.com.tr/39540-sarmasik-2015-yerli-film-izle.html)

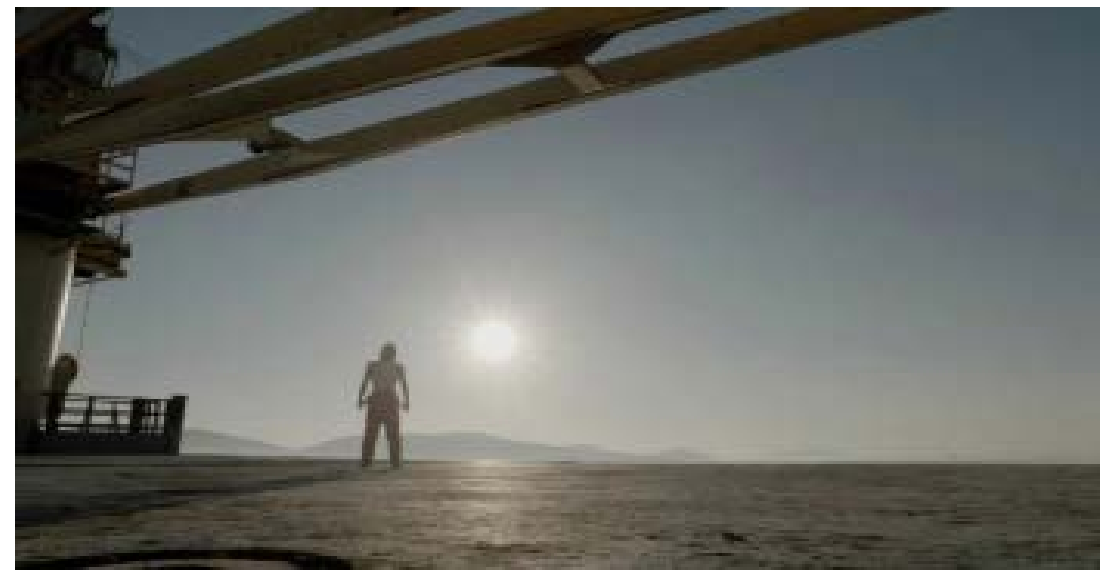

Şekil 15: Gemi ve karanın aynı düzlemde gösterildiği bu sahne ile gemide hapsolma hali vurgulanır. (Kaynak: http://www.vizyonfilmizle.com.tr/39540-sarmasik-2015-yerli-film-izle.html)

Bu mekân odaklı sahnelerle hem yük gemisinin mekânsal ve işlevsel nitelikleri izleyiciye tanıtılır, hem de "sinematik mekân araçsallaşır, 'tek başrol' kimliği kazanır, söylenmek istenen şeyi vurgular ve anlamlar üretir; yani konuşur" (Uzunali, 2015, s. 
22). Öte yandan, filmin değişen ve dönüşen iktidar ilişkilerini anlama eğilimi ve toplumsal konulara yaptığı göndermeler dikkate alındığında, geminin filme ev sahipliği yapmasının yanında mekânsal yönden de sembolik anlamlar ihtiva ettiği ifade edilebilir. Zira film ilerledikçe çoğalan sorunlarla birlikte içindeki herkesin çözümsüzlük ve bunalım duygularına teslim olduğu geminin, bütün bir tek mekân olarak toplumsal hayatı, onun belli sorunlar içeren yapısını ve diğer genel karakteristiklerini de temsil eder şekilde bir işlevsel ve mekânsal kurguda ele alındığı yönünde bir üst ölçekli okuma yapmak mümkündür.

\section{Sonuç}

Sarmaşık filmi, iktidarın gücünü değişen koşullara bağlı olarak yavaş yavaş kaybetmesi sürecinde geçirebildiği evreleri; hareket etmediği için varlık amacını yitiren ve normal yaşantının sürdürülemez hale geldiği bir yük gemisinde yaratılan mikro dünya üzerinden anlamaya çalışır. Yük gemisinin hiyerarşik yapısı ve mekânsal nitelikleri ile geminin durması sonrası hapsolunma halini betimlemek için yapılan mekân odaklı çekimler başta olmak üzere kullanılan çeşitli sinematik araçlar, filmin bu anlatısını güçlü kılma noktasında başat rol oynarlar. Özellikle mekân kullanımındaki başarıyla yaratılan gerilim, arzulanan his ve düşüncenin aktarımında etkin bir rol oynar. Filmin esas derdi olan iktidar olgusunu anlama düşüncesi noktasında en göze çarpan husus, Beybaba'nın film boyunca elinde tutmak için çeşitli yollar denediği ve son sahneye kadar bunu başardığı sarkastik iktidar imgesine karşı gemi mürettebatı eliyle ortak ve sonuca götüren hiçbir tepkinin üretilememesidir. Haksızlığın çok net olduğu durumlarda dahi kaotik bir şekilde söz konusu erk asla aşılamadığı gibi, bunun nasıl yapılacağına dair bir farkındalık ve insiyatif de ortaya konulamaz. Gemi hiyerarşisinin karakterler üzerindeki yerleşik etkisinin de bu durumda payı olduğu iddia edilebilecek olsa da, koşulların dayanılmaz hale gelmesine rağmen ortak tepki verilememiş olmasını, geminin hak arama bilincine sahip bireylerden ziyade iktidar erkini kabullenen ve tepki veremeyen bireylerden müteşekkil olması ile açıklamak mümkündür.

Toplumsal hayatla örtüşme noktasında filmin yakaladığı diğer bir önemli ayrıntı da, çeşitli iktidar biçimlerinin kendi etkinliğini sürekli korumak için farklı formlara bürünebilmesi ve derin çelişkileri barındıran eylemler içine girebilmesidir. İktidarın bu yapısıyla diyalektik bir bağa sahip olan yönetilenler penceresinden baktığımızda ise, filmde özellikle Cenk ve nispeten Alper karakteriyle anlatılan ve toplumsal hayatımızda da ciddi ölçüde karşıııkları olan figürler karşımıza çıkar. Bir yandan alkol ve uyuşturucu kullanıp sürekli isyan eden görüntüleri ile modern bir portre çizen bu figürler, öte yandan otoriteyle direkt karşılaşıldığında hiçbir şey yapamayıp kırılganlıklar içeren tavırlar sergileyerek toplumsal yapıda mevcut tanımsız, kimlik bilinci henüz oluşmamış ve bu yönleriyle de kolay idare edilebilen tipolojileri temsil ederler. Yazıda film üzerinden ele alınan erkeklik olgusu bağlamında bir değerlendirme yapıldığında da bu duruma benzer bir tablo karşımıza çıkar. Filmde kısmen ortaya konulduğu üzere kendisini cinsiyetçilik ve hegemonya odaklı ilişkiler üzerinden var eden erkeklik, işlevi biten ya da azalan ve haksızlıklar yapan bir iktidar yapısına dahi rasyonel bir tepki üretemediği ve bu konuda belirleyici bir rol üstlenemediği gibi; bu tarz bir iktidarı eleştirirken bir yandan da farkında olmadan onu üreten bir kimlikte karşımıza çıkar. Sonuç olarak da, filmin merkezinde yer alan iktidar mücadelesini yürütme araçlarından biri olan ve sosyal hayatta çeşitli biçimlerde karşımıza çıkan erkeklik imgesinin bizatihi kendisi de, filme dair yapılan incelemelerde de ortaya çıktığı üzere mikro ve makro ölçekte çeşitli toplumsal tahakkümler üretir. 


\section{KAYNAKÇA}

Acaroğlu, Devrim \& Günerbüyük, Çağdaş. “Emin Alper, ödüllü ikinci filmi 'Abluka'yı anlattı: Gerçek hayatta abluka daha sert", https://www.evrensel.net/haber/264514 İstanbul, (07 Kasım 2015), (Erişim: 02 Aralık 2016, saat: 11.45)

Adorno, T. Otoritaryen Kişilik Üstüne. Doğan Şahiner (Çev.), Om Yayınları, İstanbul 2003.

Arık, Hülya. "Kahvehanede Erkek Olmak: Kamusal Alanda Erkek Egemenliğin Antropolojisi", Cins Cins Mekân. Ayten Alkan (Derl.), Varlık Yayınları, İstanbul 2009, s. 168-202.

Arslan, Umut Tümay. Bu Kâbuslar Neden Cemil? Yeşilçam'da Erkeklik ve Mazlumluk, Metis Yayınları, Ekim, İstanbul 2005.

Bıçak, Başak. "Tolga Karaçelik: Düğün Dernek'i Gişeye Gömeceğim”, http://www.otekisinema.com, (10 Aralık 2015a), (Erişim: 18 Kasım 2016, saat: 22.50)

Connell, R. W. Toplumsal Cinsiyet ve Iktidar, Çeviren: Cem Soydemir, Ayrıntı Yayınları, İstanbul 1998.

Connell, R. W. Masculinities, University of California Press, August, Berkeley 2005.

Çiçekoğlu, Feride. Vesikalı Şehir, Metis Yayınları, 2. Baskı, Mart, İstanbul 2014.

Durmaz, Gönül. "Yaşlı Gemici ve Sarmaşık: Film Analizi”, http://devfilmsanat.com/yasligemici-ve-sarmasikfilm-analizil, (08 Aralık 2015) (Erişim: 20 Kasım 2016, saat: 21.45)

Elmacı, Tuğba. "Fantastik Eril Özne", Türk Film Araştırmalarında Yeni Yönelimler 10: Sinema ve Hayal, Bağlam Yayınları, Mayıs, İstanbul 2013.

Ercivan, Ali. "Dört Yanımız Çevrili, http://www.beyazperde.com/filmler/film-203102/, Beyazperde Eleştirisi, (2013), (Erişim: 03 Aralık 2016, saat: 18.50)

Eyiişleyen, N. Representations of Masculinities in post-1990s Turkish Cinema. Bahçeşehir Üniversitesi Sosyal Bilimler Enstitüsü, İstanbul 2010.

Foucault, Michel. Hapishanenin Doğuşu. Çeviren: Mehmet Ali Kılıçbay, 3. Baskı, İmge Kitabevi, İstanbul 2006.

Foucault, Michel. Iktidarın Gözü. Çeviren: Ferda Keskin, 3. Baskı, Ayrıntı Yayınları, İstanbul 2007.

“Gerçekten Hepimiz Aynı Gemide Miyiz!”, Hürriyet. http://www.hurriyet.com.tr/hepimizicevreleyen-iktidar-uzerine, (29 Ocak 2016), (Erişim: 20 Kasım 2016, saat: 23.00)

Goffman, Erwing. Asylums. Anchelor Books, New York 1961.

Gönülşelen, Nuray. 'Sarmaşık: Bir 'Cenk' Hikâyesi”, http://bianet.org/biamag/sanat/170045-sarmasik-bir-cenk-hikayesi, (12 Aralık 2015), (Erişim: 19 Kasım 2016, saat: 12.50) 
Günerbüyük,

Çağdaş.

"Burada

mı

Kalmıştık", https://www.evrensel.net/yazi/75437/burada-mi-kalmistik, (04 Aralık 2015), (Erişim: 24 Kasım 2016, saat: 20.00)

Irmak, Mustafa. "Abluka", http://www.filmelestirisi.com/elestiri/abluka, (2015) (Erişim: 01 Aralık 2016, saat: 20.50)

Kiesling, Scott. F. "Power and the Language of Men", Language and Masculinity. S. Johnson ve U. Meinhof (eds.), Oxford: Blackwell 1997, s. 65-86.

Konuşlu, Fırat. "Tepenin Bu Yanı: Mekânsal Bağlamda Tepenin Ardı", Altyazı Aylık Sinema Dergisi, http://www.altyazi.net/yazilar/tepenin-bu-yani-mekansal-baglamdatepenin-ardi/ (7 Şubat 2013) (Erişim: 05 Aralık 2016, saat: 10.30)

Korkut, Ayşe (Ekleyen). "Sarmaşık - Aynı Geminin İnsanları: Full Review", http://ekrandedektifi.com/sarmasik-ayni-geminin-insanlari, (7 Aralık 2015), (Erişim: 14 Kasım 2016, saat: 16.30)

Kutay, Uğur. Sinema-Politik Sosyo-Semiyoloji Notları, Es yayınları, Ocak, İstanbul 2011.

Neale, Steve. "Masculinity as Spectacle", Screen 24 (6), 1983, s. 2-17

Oktan, Ahmet. "Türk Sinemasında Hegemonik Erkeklikten Erkeklik Krizine: Yazı-Tura ve Erkeklik Bunalımının Sınırları”, Selçuk İletişim 5-2, 2008, s. 152-166.

Özdaş, Recep. "Buram Buram Angst Erkeklik", https://www.cine35mm.com/tr/review/10143/sarmasik, (24 Aralık 2015), (Erişim: 15 Kasım 2016, saat: 21.20)

Öztürk, Serdar. Mekân ve Iktidar; Filmlerle Iletişim Mekânlarının Alt politikası, Phoenix Yayınevi, Temmuz, Ankara 2012.

Ryan, Michael \& Kellner, Douglas. Politik Kamera Çağdaş Hollywood Sinemasının Ideolojisi ve Politikası, Çeviren: Elif Özsayar, Ayrıntı Yayınları, 2. Baskı, İstanbul 2010.

Suner, Asuman. Hayalet Ev Yeni Türk Sineması'nda Aidiyet, Kimlik ve Bellek, Metis Yayınları, 1. Baskı, Nisan, İstanbul 2006.

Taşıtman, Ayşegül. "Kutsal Erkekliğin İnşasında Bir Durak: Sünnet Ritüeli", Bellek İleri: Kurgudan Kurama Görüntüler, Kalkedon Yayınları, İstanbul 2012, s. 109-131.

"Tolga Karaçelik'in 'Sarmaşık'ına İtalya'dan Ödül”, Kültür Servisi https://www.evrensel.net/haber/278677/tolga-karacelikin-sarmasik-ina-italyadan-odul, (28 Nisan 2016), (Erişim: 16 Kasım 2016, saat: 13.30)

Ulusay, N. "Günümüz Türk Sinemasında ‘Erkek Filmleri'nin Yükselişi ve Erkeklik Krizi”, Toplum ve Bilim Dergisi. Sayı: 101, 2004.

Umut, M. Representations of Masculinities in the Post-1960s Turkish Cinema. Sabancı Üniversitesi Sosyal Bilimler Enstitüsü, İstanbul 2007. 
Uzunali, Görkem. Zeki Demirkubuz Sinemasında Mekân Kullanımı, Yüksek Lisans Tezi, Hacettepe Üniversitesi Sosyal Bilimler Enstitüsü İletişim Bilimleri Anabilim Dalı, Ankara 2015.

"Yer Gösterici'nin Konuğu Sarmaşık Filmi'nin Yönetmeni Tolga Karaçelik (Söyleşi)", Yer Gösterici. https://www.youtube.com/watch?v=aF8mAUEplsg, (09 Aralık 2015b), (Erişim: 08 Kasım 2016, saat: 22.20)

Yiğit, Karaca. "Homososyallik", Dosya: Yeni Türkiye Sineması ve Erkeklik Temsili. http://sinegoz.com/dosya/yeni-turkiye-sinemasi-erkeklik-temsili/, (18 Nisan 2015), (Erişim: 26 Kasım 2016, saat: 19.00) 